\title{
Theoretical and Experimental Study of Vanadium-Based Fluorophosphate Cathodes for Rechargeable Batteries
}

\author{
Maowen $\mathrm{Xu},{ }^{\dagger, \S, \|}$ Penghao Xiao, ${ }^{\ddagger}, \|$ Shannon Stauffer, ${ }^{\dagger}$ Jie Song, ${ }^{\dagger}$ Graeme Henkelman, ${ }^{*}, \dagger, \ddagger$ \\ and John B. Goodenough $* \dagger$
}

${ }^{\dagger}$ Texas Materials Institute and Department of Chemistry and the Institute for Computational Engineering and Sciences, University of Texas at Austin, Austin, Texas 78712, United States

${ }^{\S}$ Institute for Clean Energy \& Advanced Materials, Southwest University, Chongqing 400715, P. R. China

\begin{abstract}
A single-phase crystalline $\mathrm{Na}_{3} \mathrm{~V}_{2} \mathrm{O}_{2}\left(\mathrm{PO}_{4}\right)_{2} \mathrm{~F}$ material has been prepared by the solvothermal method. Partial ion exchange between $\mathrm{Na}$ and $\mathrm{Li}$ was then used to form $\mathrm{Na}_{3-x} \mathrm{Li}_{x} \mathrm{~V}_{2} \mathrm{O}_{2}\left(\mathrm{PO}_{4}\right)_{2} \mathrm{~F}$. The two materials were studied as positive cathodes by physical characterization, electrochemical measurements, and simulation. With density functional theory calculations, four stable phases of $\mathrm{Na}_{x} \mathrm{~V}_{2} \mathrm{O}_{2}\left(\mathrm{PO}_{4}\right)_{2} \mathrm{~F}$ were identified at the $\mathrm{Na}$ concentrations of $x=0,1,2,3$. The transitions between these phases give rise to three values of the $\mathrm{Na}$ chemical potential and three voltage plateaus for $\mathrm{Na}$

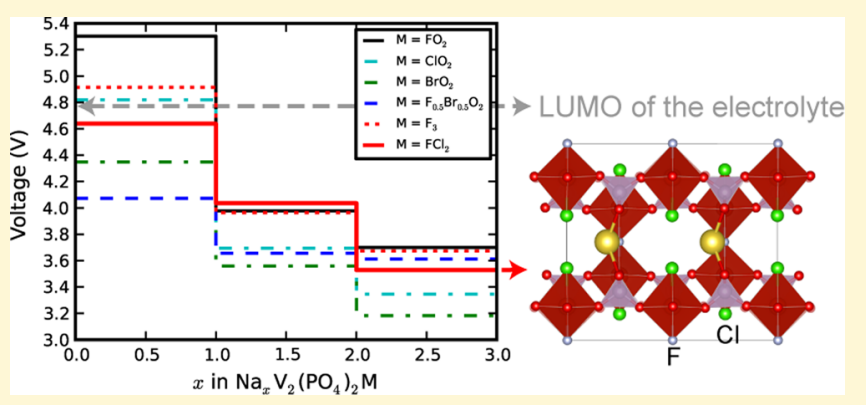
intercalation. The lower two voltages, corresponding to removal of the first two $\mathrm{Na}$ per formula unit, agree well with the corresponding experimental electrochemical measurements. Removal of the third $\mathrm{Na}$, however, is not observed experimentally, because it is outside of the (4.8 V) stability window of the electrolyte. This observation is consistent with our calculations that show that the last Na will only be removed at $5.3 \mathrm{~V}$, owing to the stability of the $\mathrm{V}-\mathrm{O}$ bonding state and a strong Coulomb attraction between the $\mathrm{Na}$ and the anions. Computational modifications of the material were considered to activate the third $\mathrm{Na}$ with an oxidation energy in the electrolyte stability window, including swapping the anions from $\mathrm{O}$ and $\mathrm{F}$ to less-electronegative $\mathrm{Cl}$ and $\mathrm{Br}$. The most promising material, $\mathrm{Na}_{3} \mathrm{~V}_{2} \mathrm{Cl}_{2}\left(\mathrm{PO}_{4}\right)_{2} \mathrm{~F}$, is found to be stable and a good candidate as a $\mathrm{Na}$ cathode because all three $\mathrm{Na}$ ions can be reversibly removed without significant reduction in the cell potential or energy density of the material. Finally, we show that Li can partially replace $\mathrm{Na}$ and that these $\mathrm{Li}$ intercalate into the material with a higher rate owing to a lower diffusion barrier as compared to Na.
\end{abstract}

\section{INTRODUCTION}

Energy demand is expected to increase considerably in the coming years as a result of population growth and economic development. However, the dependence of modern society on fossil fuels is not sustainable. One driver for the development of the rechargeable Li-ion battery is the need to store electrical energy generated by wind and solar energy. ${ }^{1-3}$ An assessment of lithium reserves reveals that most of them are located in politically sensitive areas, ${ }^{4}$ which has prompted interest in the $\mathrm{Na}$-ion battery owing to the wide availability of low-cost $\mathrm{Na}^{5-8}$

Extensive research has been reported recently on polyanionbased cathodes for a sodium ion battery with an open framework for fast diffusion of mobile ions. Examples include sodium fluorophosphates, $\mathrm{NaVPO}_{4} \mathrm{~F}, \mathrm{Na}_{2} \mathrm{MPO}_{4} \mathrm{~F}(\mathrm{M}=\mathrm{Fe}$, $\mathrm{Mn}, \mathrm{Co}),{ }^{9} \mathrm{Na}_{3} \mathrm{~V}_{2} \mathrm{O}_{2}\left(\mathrm{PO}_{4}\right)_{2} \mathrm{~F},{ }^{10} \mathrm{Na}_{3} \mathrm{~V}_{2}\left(\mathrm{PO}_{4}\right)_{2} \mathrm{~F}_{3},{ }^{11,12}$ $\mathrm{Na}_{1.5} \mathrm{VPO}_{4.8} \mathrm{~F}_{0.7}{ }^{27}$ and $\mathrm{Li}_{1.1} \mathrm{Na}_{0.4} \mathrm{VPO}_{4.8} \mathrm{~F}_{0.7}{ }^{13}$ However, despite their fast ionic conduction, their low energy density makes them less attractive as electrode materials. $\mathrm{Na}_{3} \mathrm{~V}_{2} \mathrm{O}_{2}\left(\mathrm{PO}_{4}\right)_{2} \mathrm{~F}$ as a sodium ion battery cathode has a theoretical specific capacity of $130 \mathrm{mAh} \mathrm{g}^{-1}$ with two $\mathrm{Na}$ per formula unit that can be cycled reversibly. With two voltage plateaus at 3.7 and $4.0 \mathrm{~V}$, the corresponding energy density is $501 \mathrm{Wh} \mathrm{kg}^{-1}$. The ability to cycle all the $\mathrm{Na}$ would increase the capacity to $195 \mathrm{mAh} \mathrm{g}^{-1}{ }^{14}$
While there is a lot of experimental data on vanadium-based fluorophosphate cathodes, little is known about structural variations of vanadium-based fluorophosphate cathodes during the $\mathrm{Na} / \mathrm{Li}$ insertion process.

In this work, a single-phase, crystalline $\mathrm{Na}_{3} \mathrm{~V}_{2} \mathrm{O}_{2}\left(\mathrm{PO}_{4}\right)_{2} \mathrm{~F}$ material was prepared by the solvothermal method. The $\mathrm{Na}_{3-x} \mathrm{Li}_{x} \mathrm{~V}_{2} \mathrm{O}_{2}\left(\mathrm{PO}_{4}\right)_{2} \mathrm{~F}$ material was subsequently obtained from $\mathrm{Na}_{3} \mathrm{~V}_{2} \mathrm{O}_{2}\left(\mathrm{PO}_{4}\right)_{2} \mathrm{~F}$ by $\mathrm{Na} / \mathrm{Li}$ ion exchange. Computer simulations were combined with electrochemical analysis in order to understand the electrochemical properties of the asprepared materials as cathodes for rechargeable batteries and how to make these vanadium-based fluorophosphates cathodes offer a higher energy density. We suggest new polyanion frameworks in which $\mathrm{Cl}$ is substituted for $\mathrm{O}$ as a promising way to enhance the capacity of $\mathrm{Na}_{3} \mathrm{~V}_{2} \mathrm{O}_{2}\left(\mathrm{PO}_{4}\right)_{2} \mathrm{~F}$ at the electrode without sacrificing voltage.

Received: January 10, 2014

Revised: April 28, 2014

Published: May 14, 2014 

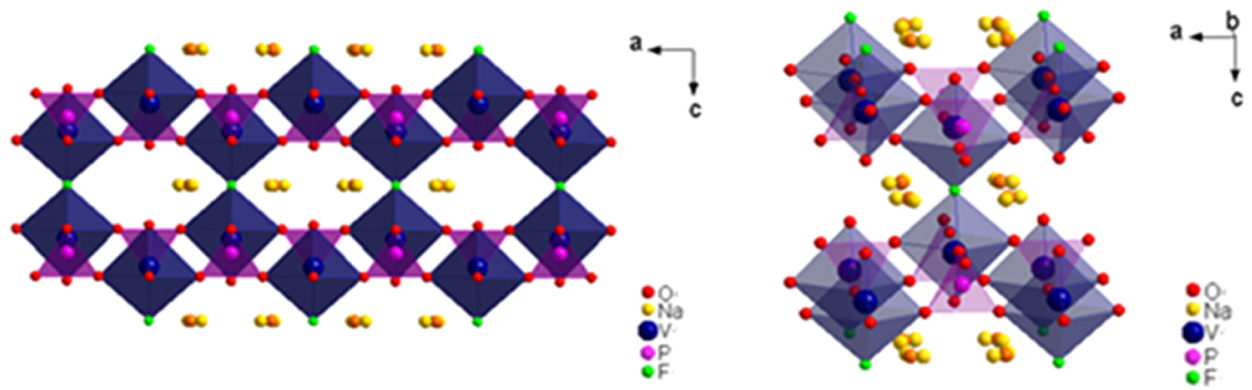

Figure 1. (a) Structure of the $\mathrm{Na}_{3} \mathrm{~V}_{2} \mathrm{O}_{2}\left(\mathrm{PO}_{4}\right)_{2} \mathrm{~F}$ projected onto the $c-a$ plane and (b) an alternative representation.
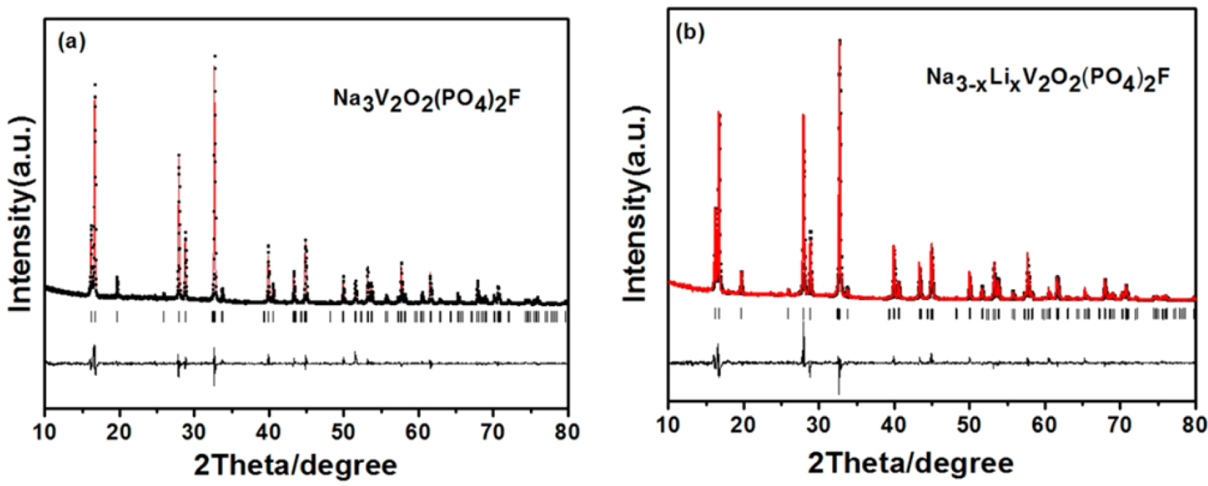

Figure 2. XRD pattern of (a) $\mathrm{Na}_{3} \mathrm{~V}_{2} \mathrm{O}_{2}\left(\mathrm{PO}_{4}\right)_{2} \mathrm{~F}$ and (b) $\mathrm{Na}_{3-x} \mathrm{Li}_{x} \mathrm{~V}_{2} \mathrm{O}_{2}\left(\mathrm{PO}_{4}\right)_{2} \mathrm{~F}$; the experimental data (black crosses), calculated patterns (red line), and the difference (blue line) are shown.

\section{RESULTS AND DISCUSSION}

Figure 1 shows the structure of $\mathrm{Na}_{3} \mathrm{~V}_{2} \mathrm{O}_{2}\left(\mathrm{PO}_{4}\right)_{2} \mathrm{~F}$. Pairs of $\mathrm{VO}_{5} \mathrm{~F}$ octahedra oriented parallel to the $b$ axis share a common $\mathrm{F}$ corner, the opposite ligand is an $\mathrm{O}$ atom that binds with only one $\mathrm{V}$ atom. Each bioctahedron shares eight of its oxygen vertices with $\left(\mathrm{PO}_{4}\right)$ tetrahedral units; interstitial channels form along the $a$ and $b$ axes as well as large cavities. The sodium ions in the interstitial spaces are disordered over two distinct positions separated by a small distance. The large tunnel structure is conducive to high sodium ion mobility.

The XRD patterns and full pattern refinement of (a) $\mathrm{Na}_{3} \mathrm{~V}_{2} \mathrm{O}_{2}\left(\mathrm{PO}_{4}\right)_{2} \mathrm{~F}$ and $(\mathrm{b}) \mathrm{Na}_{3-x} \mathrm{Li}_{x} \mathrm{~V}_{2} \mathrm{O}_{2}\left(\mathrm{PO}_{4}\right)_{2} \mathrm{~F}(x \approx 2)$ are shown in Figure 2. All the Bragg peaks could be indexed in a tetragonal structure with space group $\mathrm{I} / \mathrm{mmm}$ (No. 139) for $\mathrm{Na}_{3} \mathrm{~V}_{2} \mathrm{O}_{2}\left(\mathrm{PO}_{4}\right)_{2} \mathrm{~F}$ and $\mathrm{Na}_{3-x} \mathrm{Li}_{x} \mathrm{~V}_{2} \mathrm{O}_{2}\left(\mathrm{PO}_{4}\right)_{2} \mathrm{~F}$, respectively. No impurity phases were observed.

Partial ion exchange of the sodium cations for lithium within the lattice was accomplished by refluxing $\mathrm{Na}_{3} \mathrm{~V}_{2} \mathrm{O}_{2}\left(\mathrm{PO}_{4}\right)_{2} \mathrm{~F}$ in a solution of $\mathrm{LiBr}$ with a process described in the literature. ${ }^{13}$ The inductively coupled plasma (ICP) technique was used to quantitatively analyze the composition of the products. Combined with XPS analysis, the product obtained in the ion exchange experiment is $\mathrm{Na}_{3-x} \mathrm{Li}_{x} \mathrm{~V}_{2} \mathrm{O}_{2}\left(\mathrm{PO}_{4}\right)_{2} \mathrm{~F}$ with $x=0.57$. However, after cycling in a battery with a $\mathrm{Li}$ anode, a higher value of $x$ is expected. An increasing amount of $\mathrm{Li}$ is also reflected in the lattice parameter change in Table 1

Figure 3 shows SEM images of the two samples; the exchange of $\mathrm{Na}$ for $\mathrm{Li}$ causes a significant change in morphology. It can be observed that $\mathrm{Na}_{3} \mathrm{~V}_{2} \mathrm{O}_{2}\left(\mathrm{PO}_{4}\right)_{2} \mathrm{~F}$ has a square-column morphology with an average grain length of 10 $\mu$ m (Figure 3a). In contrast, $\mathrm{Na}_{3-x} \mathrm{Li}_{x} \mathrm{~V}_{2} \mathrm{O}_{2}\left(\mathrm{PO}_{4}\right)_{2} \mathrm{~F}$ obtained via $\mathrm{Na}_{3} \mathrm{~V}_{2} \mathrm{O}_{2}\left(\mathrm{PO}_{4}\right)_{2} \mathrm{~F}$ by $\mathrm{Na} / \mathrm{Li}$ ion exchange loses the precursor's pristine square-column and is dominated by
Table 1. Lattice Parameters (in the space group $14 / \mathrm{mmm}$ ) Obtained by the Full Pattern Matching of the XRD Patterns of $\mathrm{Na}_{3} \mathrm{~V}_{2} \mathrm{O}_{2}\left(\mathrm{PO}_{4}\right)_{2} \mathrm{~F}$ and $\mathrm{Na}_{3-x} \mathrm{Li}_{x} \mathrm{~V}_{2} \mathrm{O}_{2}\left(\mathrm{PO}_{4}\right)_{2} \mathrm{~F}$

\begin{tabular}{lcccc}
\multicolumn{1}{c}{ composition } & $a(\AA)$ & $b(\AA)$ & $c(\AA)$ & cell volume $\left(\AA^{3}\right)$ \\
$\mathrm{Na}_{3} \mathrm{~V}_{2} \mathrm{O}_{2}\left(\mathrm{PO}_{4}\right)_{2} \mathrm{~F}$ & 6.3882 & 6.3882 & 10.6309 & 433.8386 \\
$\mathrm{Na}_{3-x} \mathrm{Li}_{x} \mathrm{~V}_{2} \mathrm{O}_{2}\left(\mathrm{PO}_{4}\right)_{2} \mathrm{~F}$ & 6.3831 & 6.3831 & 10.6120 & 432.3715 \\
3 cycles with Li & 6.3631 & 6.3631 & 10.6319 & 430.4807 \\
20 cycles with Li & 6.3543 & 6.3543 & 10.6226 & 428.9106 \\
\hline
\end{tabular}

irregularly shaped grains (Figure $3 b$ ), which is mainly due to the harsh environment of the ion-exchange process.

Figure 4 compares the electrochemical behavior of the $\mathrm{Na}_{3} \mathrm{~V}_{2} \mathrm{O}_{2}\left(\mathrm{PO}_{4}\right)_{2} \mathrm{~F} / \mathrm{Na}$ and $\mathrm{Na}_{3-x} \mathrm{Li}_{x} \mathrm{~V}_{2} \mathrm{O}_{2}\left(\mathrm{PO}_{4}\right)_{2} \mathrm{~F} / \mathrm{Li}$ cells. In our study, the charge/discharge voltage range was set from 2.5 to $4.6 \mathrm{~V}$. The galvanostatic charge/discharge curve and corresponding $\mathrm{d} q / \mathrm{d} V$ plot (inset) of a $\mathrm{Na}_{3} \mathrm{~V}_{2} \mathrm{O}_{2}\left(\mathrm{PO}_{4}\right)_{2} \mathrm{~F} / \mathrm{Na}$ half-cell show two plateaus at ca. 3.65 and $4.05 \mathrm{~V}$ on charge and 4.0 and $3.6 \mathrm{~V}$ on discharge (Figure $4 \mathrm{a}$ ). The charge/discharge profiles of the $\mathrm{Na}_{3-x} \mathrm{Li}_{x} \mathrm{~V}_{2} \mathrm{O}_{2}\left(\mathrm{PO}_{4}\right)_{2} \mathrm{~F} / \mathrm{Li}$ half-cell in Figure $4 \mathrm{~b}$ show two plateaus, one at $4.25 / 4.21 \mathrm{~V}$ and the other at 3.86/ $3.80 \mathrm{~V}$. This result demonstrates that the open framework can provide acceptable $\mathrm{Li}$ and $\mathrm{Na}$ mobility.

Figure 5 shows the discharge capacity of the $\mathrm{Na}_{3} \mathrm{~V}_{2} \mathrm{O}_{2}\left(\mathrm{PO}_{4}\right)_{2} \mathrm{~F} / \mathrm{Na}$ and $\mathrm{Na}_{3-x} \mathrm{Li}_{x} \mathrm{~V}_{2} \mathrm{O}_{2}\left(\mathrm{PO}_{4}\right)_{2} \mathrm{~F} / \mathrm{Li}$ cells at different discharge currents. Changes in $\mathrm{C}$-rate (i.e., current density) resulted in a stepwise dependence of the specific capacity. In the $\mathrm{Na}_{3} \mathrm{~V}_{2} \mathrm{O}_{2}\left(\mathrm{PO}_{4}\right)_{2} \mathrm{~F} / \mathrm{Na}$ cell, the observed decrease in specific capacity is small, from 102 to $93 \mathrm{mAh}$ $\mathrm{g}^{-1}$, respectively, as the $C$-rate is increased from 0.05 to $0.1 \mathrm{C}$ (Figure 5a). Further increase of the $C$-rate to $1 \mathrm{C}$ greatly reduces the capacity from 92 to $58 \mathrm{mAh} \mathrm{g}^{-1}$. While the capacity is reduced at higher $C$-rates, the cyclic retention is maintained. Upon increasing the cycling rate from 1 to $10 \mathrm{C}$, the specific 

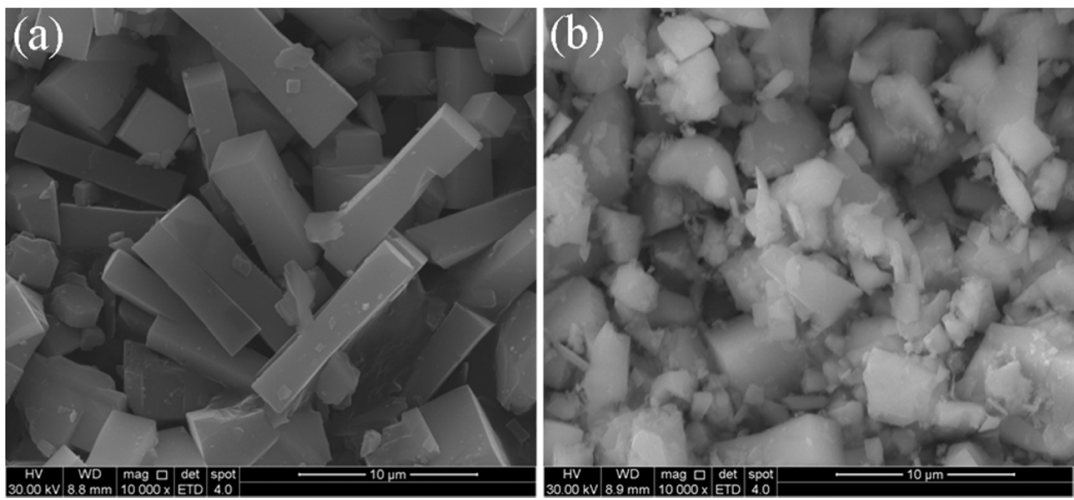

Figure 3. SEM images of (a) $\mathrm{Na}_{3} \mathrm{~V}_{2} \mathrm{O}_{2}\left(\mathrm{PO}_{4}\right)_{2} \mathrm{~F}$ prepared by the hydrothermal method at $180{ }^{\circ} \mathrm{C}$ and (b) $\mathrm{Na}_{3-x} \mathrm{Li}_{x} \mathrm{~V}_{2} \mathrm{O}_{2}\left(\mathrm{PO}_{4}\right)_{2} \mathrm{~F}$ obtained via $\mathrm{Na}_{3} \mathrm{~V}_{2} \mathrm{O}_{2}\left(\mathrm{PO}_{4}\right)_{2} \mathrm{~F}$ as a precursor by $\mathrm{Na} / \mathrm{Li}$ ion exchange.
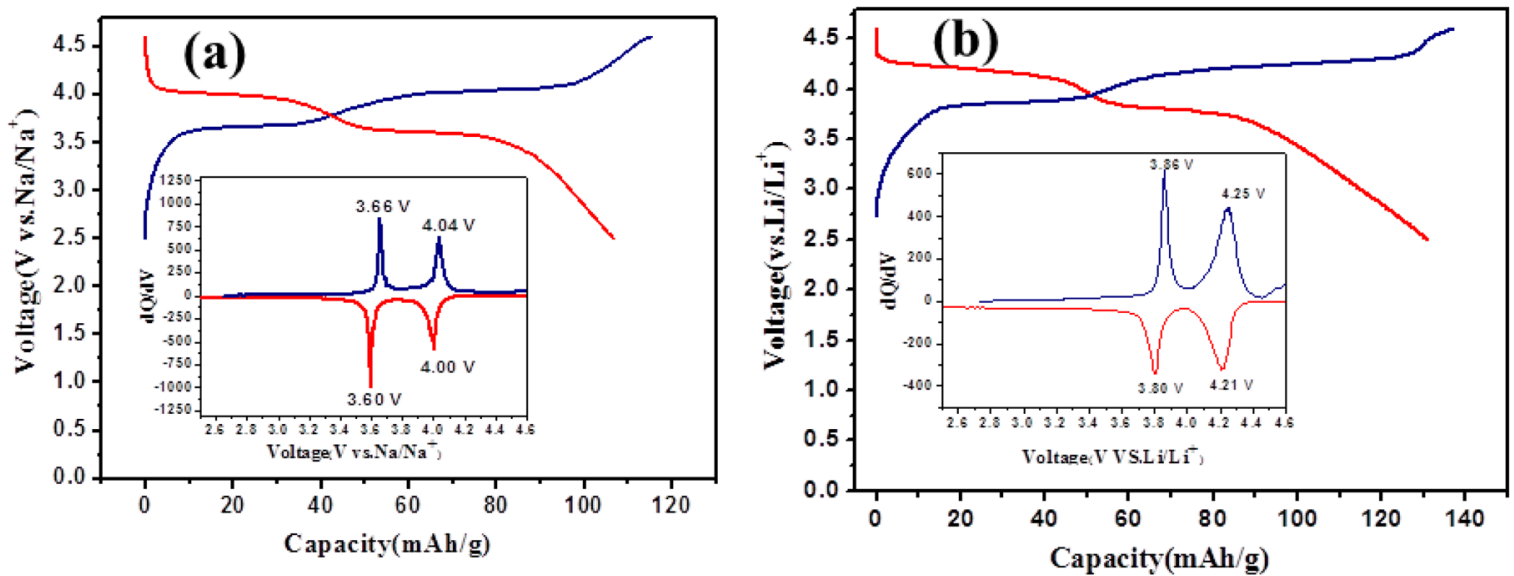

Figure 4. Charge and discharge profiles recorded at the second cycle of (a) $\mathrm{Na}_{3} \mathrm{~V}_{2} \mathrm{O}_{2}\left(\mathrm{PO}_{4}\right)_{2} \mathrm{~F}$ and $(\mathrm{b}) \mathrm{Na}_{3-x} \mathrm{Li}_{x} \mathrm{~V}_{2} \mathrm{O}_{2}\left(\mathrm{PO}_{4}\right)_{2} \mathrm{~F}$. Insets show chronoamperograms of $\mathrm{Na}_{3} \mathrm{~V}_{2} \mathrm{O}_{2}\left(\mathrm{PO}_{4}\right)_{2} \mathrm{~F}$ and $\mathrm{Na}_{3-x} \mathrm{Li}_{x} \mathrm{~V}_{2} \mathrm{O}_{2}\left(\mathrm{PO}_{4}\right)_{2} \mathrm{~F}$, respectively.
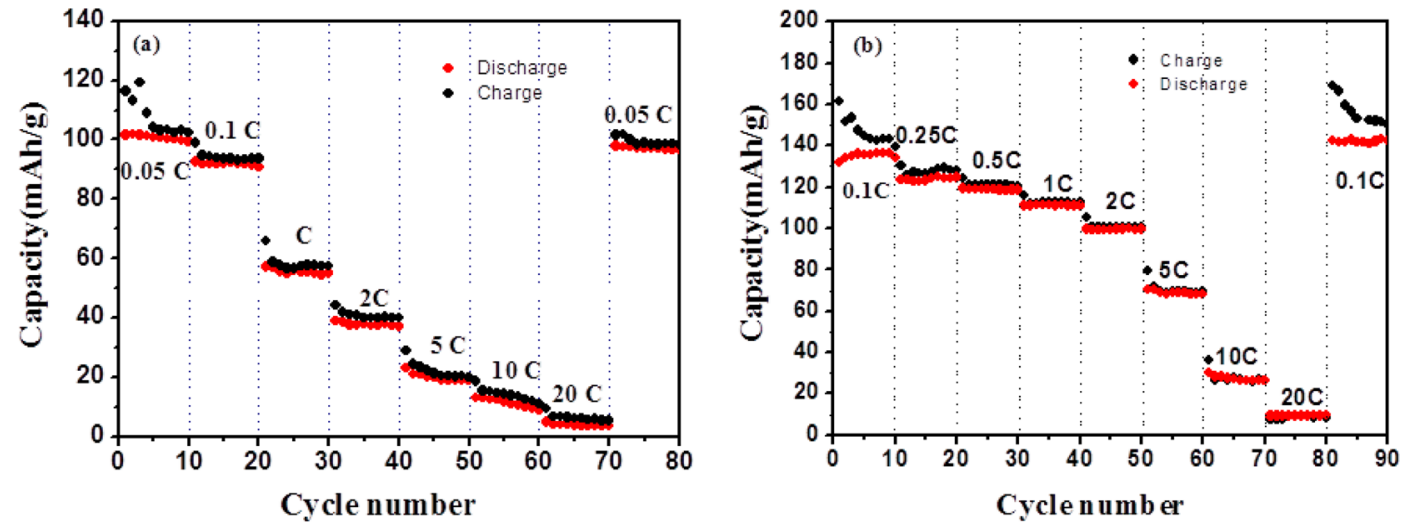

Figure 5. (a) Cycling of (a) $\mathrm{Na}_{3} \mathrm{~V}_{2} \mathrm{O}_{2}\left(\mathrm{PO}_{4}\right)_{2} \mathrm{~F} / \mathrm{Na}$ and (b) $\mathrm{Na}_{3-x} \mathrm{Li}_{x} \mathrm{~V}_{2} \mathrm{O}_{2}\left(\mathrm{PO}_{4}\right)_{2} \mathrm{~F} / \mathrm{Li}$ cells at various C-rates.

capacity decreases from 58 to $18 \mathrm{mAh} \mathrm{g}^{-1}$. When the cycling rate is returned to $0.1 \mathrm{C}$, the capacity is recovered and increases from 8 at $20 \mathrm{C}$ to $102 \mathrm{mAh} \mathrm{g}^{-1}$. In the $\mathrm{Na}_{3-x} \mathrm{Li}_{x} \mathrm{~V}_{2} \mathrm{O}_{2}\left(\mathrm{PO}_{4}\right)_{2} \mathrm{~F} /$ Li cell (Figure 5b), different current rates, namely, 0.1, 0.25, 0.5, $1,2,5,10$, and $20 \mathrm{C}$, are applied to ensure capacity retention. After the $C$-rate is increased from 0.1 to 0.25 to $0.5 \mathrm{C}$ with 10 cycles at each step, the cell is cycled at $1 \mathrm{C}$ rate, where the capacity remained at $110 \mathrm{mAh} \mathrm{g}^{-1} ; 82 \%$ of the capacity was retained after 30 cycles. When the $C$ rate is increased from 1 to $2 \mathrm{C}$, the specific capacity does not decrease much, retaining 99 $\mathrm{mAh} \mathrm{g}^{-1}$. Upon returning the cell to cycling at $0.1 \mathrm{C}$ rates, the capacity recovers to $133 \mathrm{mAh} \mathrm{g}^{-1}$ and is subsequently maintained at $130 \mathrm{mAhg}^{-1}$ for at least the next 10 cycles. It can be concluded that the $\mathrm{Na}_{3-x} \mathrm{Li}_{x} \mathrm{~V}_{2} \mathrm{O}_{2}\left(\mathrm{PO}_{4}\right)_{2} \mathrm{~F} / \mathrm{Li}$ cells show good rate capability.

The average capacities of $\mathrm{Na}_{3} \mathrm{~V}_{2} \mathrm{O}_{2}\left(\mathrm{PO}_{4}\right)_{2} \mathrm{~F}$ at 1 and $2 \mathrm{C}$ are 58 and $37 \mathrm{mAh} \mathrm{g}^{-1}$, but that of $\mathrm{Na}_{3-x} \mathrm{Li}_{x} \mathrm{~V}_{2} \mathrm{O}_{2}\left(\mathrm{PO}_{4}\right)_{2} \mathrm{~F}$ is 110 and $99 \mathrm{mAh} \mathrm{g}^{-1}$, demonstrating that $\mathrm{Na}_{3-x} \mathrm{Li}_{x} \mathrm{~V}_{2} \mathrm{O}_{2}\left(\mathrm{PO}_{4}\right)_{2} \mathrm{~F} / \mathrm{Li}$ has a better $C$-rate performance than $\mathrm{Na}_{3} \mathrm{~V}_{2} \mathrm{O}_{2}\left(\mathrm{PO}_{4}\right)_{2} \mathrm{~F} / \mathrm{Na}$ cells. According to ICP and XPS analysis, originally only a small portion of $\mathrm{Na}$ was exchanged by $\mathrm{Li}$ in $\mathrm{Na}_{3-x} \mathrm{Li}_{x} \mathrm{~V}_{2} \mathrm{O}_{2}\left(\mathrm{PO}_{4}\right)_{2} \mathrm{~F}$. A significant amount of $\mathrm{Li}$ subsequently displaces $\mathrm{Na}$ in the 


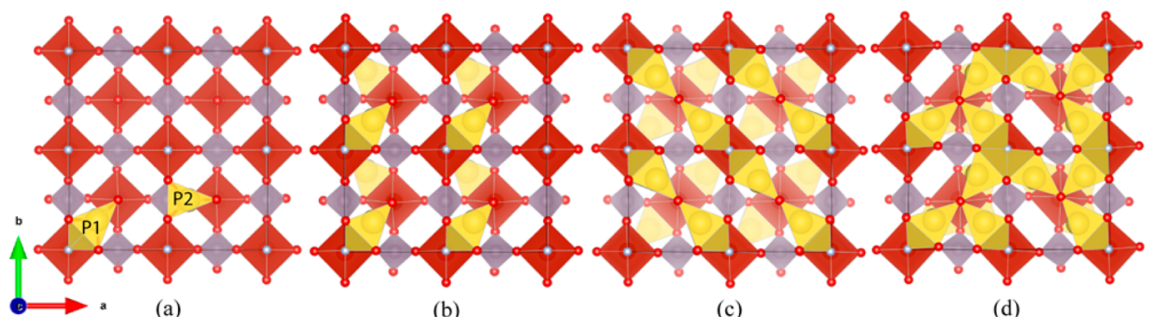

Figure 6. Most stable arrangement of $\mathrm{Na}$ in $\mathrm{Na}_{x} \mathrm{~V}_{2}\left(\mathrm{PO}_{4}\right)_{2} \mathrm{FO}_{2}$ for different compositions, $x$ : (a) two Na positions in the $\mathrm{V}_{2}\left(\mathrm{PO}_{4}\right)_{2} \mathrm{FO}_{2}$ framework, (b) $\mathrm{NaV}_{2}\left(\mathrm{PO}_{4}\right)_{2} \mathrm{FO}_{2}$, (c) $\mathrm{Na}_{2} \mathrm{~V}_{2}\left(\mathrm{PO}_{4}\right)_{2} \mathrm{FO}_{2}$, and (d) $\mathrm{Na}_{3} \mathrm{~V}_{2}\left(\mathrm{PO}_{4}\right)_{2} \mathrm{FO}_{2}$. The red atoms are $\mathrm{O}$, blue are $\mathrm{F}$, and yellow are $\mathrm{Na}$; the red polyhedra enclose the $\mathrm{V}$ atoms and the gray enclose $\mathrm{P}$.

cathode by electrochemical cycling. That a significant amount of $\mathrm{Li}$ is inserted is known from the cycled capacity from the $\mathrm{Li}$ metal anode through the Li-rich electrolyte, as well as the high conductivity of the resulting $\mathrm{Na}_{3-x} \mathrm{Li}_{x} \mathrm{~V}_{2} \mathrm{O}_{2}\left(\mathrm{PO}_{4}\right)_{2} \mathrm{~F}$ material. The significant difference in $\mathrm{C}$-rate performance is consistent with the theoretical calculations described next.

Theoretical Calculations of $\mathrm{Na}_{3} \mathrm{~V}_{2} \mathrm{O}_{2}\left(\mathrm{PO}_{4}\right)_{2} \mathrm{~F}$. Our theoretical study addresses the origin and magnitude of the voltage step after the first two $\mathrm{Na}$ are removed, at what voltage the third $\mathrm{Na}$ would be removed if further oxidation of the framework is possible, and whether an alternative chemistry with the same framework structure can allow the third $\mathrm{Na}$ to be removed at a voltage in the electrolyte window without a large sacrifice in the overall average voltage. Finally, we compare the theoretical differences between $\mathrm{Li}$ and $\mathrm{Na}$ intercalation in terms of voltage profiles and rate capabilities. For convenience of notation, we put the $\mathrm{O}$ bonded to $\mathrm{V}$ at the end of the compound formula and rewrite $\mathrm{Na}_{3} \mathrm{~V}_{2} \mathrm{O}_{2}\left(\mathrm{PO}_{4}\right)_{2} \mathrm{~F}$ as $\mathrm{Na}_{3} \mathrm{~V}_{2}\left(\mathrm{PO}_{4}\right)_{2} \mathrm{FO}_{2}$ to make a more direct connection to the $\mathrm{Na}_{3} \mathrm{~V}_{2}\left(\mathrm{PO}_{4}\right)_{2} \mathrm{~F}_{3}$ and $\mathrm{Na}_{3} \mathrm{~V}_{2}\left(\mathrm{PO}_{4}\right) \mathrm{FX}_{2}(\mathrm{X}=\mathrm{Cl}$ or $\mathrm{Br})$ that are considered subsequently. We refer to these ions as dangling because they are singly bonded to a $\mathrm{V}$ atom and not part of the $\mathrm{PO}_{4}$ groups.

There are two types of sites for $\mathrm{Na}$ to occupy in $\mathrm{V}_{2}\left(\mathrm{PO}_{4}\right)_{2} \mathrm{FO}_{2}$, as is shown in Figure 6a: the $\mathrm{P} 1$ site is coordinated by six $\mathrm{O}$ and one $\mathrm{F}$ with a binding energy of 4.70 $\mathrm{eV}$ in the dilute limit; the P2 site is coordinated by only six $\mathrm{O}$ and the binding energy is $4.62 \mathrm{eV}$. The extra $\mathrm{Na}-\mathrm{F}$ bond stabilizes the former site by $0.08 \mathrm{eV}$.

To calculate the voltage profile, formation energies of the material were calculated as a function of $\mathrm{Na}$ concentration. The lowest energy structures form the convex hull of Figure 7a. At each composition, hundreds of configurations with different $\mathrm{Na}$ arrangements are examined with the basin-hopping algorithm; only the lowest energy structures are plotted. Details of the calculations can be found in the Theoretical Methods section and ref 15 . The convex hull clearly shows four Na-ordered phases at $x=0,1,2$ and 3 , each of which are illustrated in Figure 6. Any other composition has a higher energy than the linear combination of these phases and will, therefore, tend to decompose spontaneously into the two bracketing ordered phases on the convex hull. The voltage profile is obtained from the slopes of the convex hull. The lower two voltage plateaus at 4.0 and $3.7 \mathrm{~V}$ match the experimental values. With less than one $\mathrm{Na}$ per formula unit $(x<1)$, the intercalation voltage is $5.3 \mathrm{~V}$, which is significantly above the electrochemical stability window of the electrolyte. Moreover, removal of the last $\mathrm{Na}$ would require oxidation of the $\mathrm{PO}_{4}$. In order to extract the last $\mathrm{Na}$, the binding of $\mathrm{Na}$ must be weakened in the phase where $x$ $<1$ and it must be possible to oxidize a redox couple without

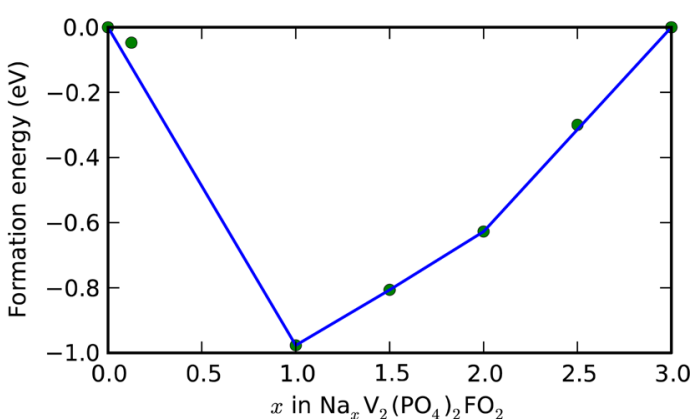

(a)

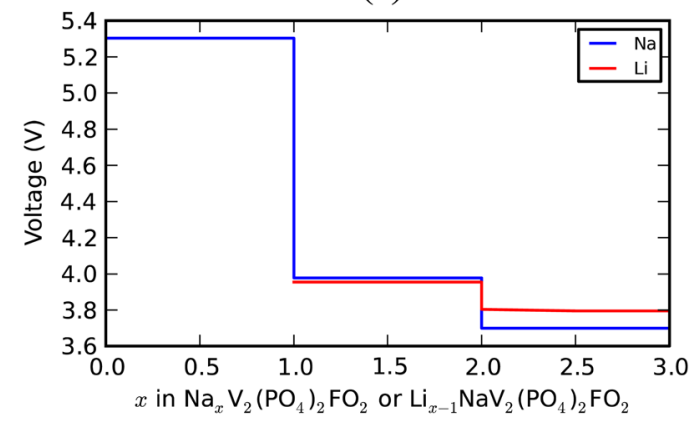

(b)

Figure 7. (a) Calculated convex hull plot for $\mathrm{Na}_{x} \mathrm{~V}_{2}\left(\mathrm{PO}_{4}\right)_{2} \mathrm{FO}_{2}$ and (b) the calculated voltage for $\mathrm{Na} / \mathrm{Li}$ intercalation in $\mathrm{Na}_{x} \mathrm{~V}_{2}\left(\mathrm{PO}_{4}\right)_{2} \mathrm{FO}_{2} /$ $\mathrm{Na}$ and $\mathrm{Li}_{x-1} \mathrm{NaV}_{2}\left(\mathrm{PO}_{4}\right)_{2} \mathrm{FO}_{2} / \mathrm{Li}$.

decomposition of the framework. It is also advantageous to maintain a consistently high voltage for phases allowing $x>1$ so as not to reduce the energy density of the material. If the $\mathrm{O}$ atoms separate from the $\mathrm{PO}_{4}$ units are replaced by halogen atoms $\mathrm{X}$, the strong covalent $\mathrm{V}-\mathrm{O}$ bond is replaced by a more ionic $\mathrm{V}-\mathrm{X}$ bond and the formal vanadium valence becomes $\mathrm{V}^{\mathrm{III}}$. The weaker covalence of the $\mathrm{V}-\mathrm{X}$ bond and the strong inductive effect of the $\mathrm{PO}_{4}$ complexes can be expected to lower the formal $\mathrm{V}^{\mathrm{IV}} / \mathrm{V}^{\mathrm{III}}$ redox couple to near that of the formal $\mathrm{V}^{\mathrm{V}} /$ $\mathrm{V}^{\mathrm{IV}}$ couple; the replacement would also provide an oxidizable redox couple for the third $\mathrm{Na}$ atom per formula unit.

In this traditional view, the reason that the last $\mathrm{Na}(x<1)$ is inaccessible is that the $\mathrm{V}$ ion cannot be oxidized to a $\mathrm{V}^{\mathrm{VI}}$ state. Young-Uk Park et al. thus proposed to add more $\mathrm{F}$ in the formula unit as $\mathrm{Na}_{3} \mathrm{~V}_{2}\left(\mathrm{PO}_{4}\right)_{2} \mathrm{~F}_{1+y} \mathrm{O}_{2-y}$ with the idea that a decrease in the $\mathrm{V}$ oxidation state should improve the capacity. ${ }^{13}$ With $y=2$, our calculations show that the first plateau is marginally reduced from 5.3 to $4.9 \mathrm{~V}$, which is still at the top of the stability voltage window of the electrolyte. As expected, recent experimental papers on $\mathrm{Na}_{3} \mathrm{~V}_{2}\left(\mathrm{PO}_{4}\right)_{2} \mathrm{~F}_{3}$ reported that only two $\mathrm{Na}$ per formula are active at the two plateaus, 4.1 and 
3.6 V, matching our calculated values. ${ }^{16,17}$ These two plateaus are close to those of $\mathrm{Na}_{3} \mathrm{~V}_{2}\left(\mathrm{PO}_{4}\right)_{2} \mathrm{FO}_{2}$, which can be explained by a model in which the energy of the formal $\mathrm{V}^{\mathrm{IV}} / \mathrm{V}^{\mathrm{III}}$ couple is lowered by changing the strongly covalent $\mathrm{V}-\mathrm{O}$ bond to a $\mathrm{V}-$ F.

The same phenomena can also be understood from a perspective in which the $\mathrm{V}$ oxidation states in the two materials are the same. DFT calculations add support to this picture; the results of a charge density analysis (see Table 2) shows that the

Table 2. Partial Atomic Charges from a Bader Analysis

\begin{tabular}{lcccc} 
& dangling $\mathrm{O} / \mathrm{F}$ & $\mathrm{O}$ in $\mathrm{PO}_{4}$ & $\mathrm{~F}$ & $\mathrm{~V}$ \\
$\mathrm{Na}_{3} \mathrm{~V}_{2}\left(\mathrm{PO}_{4}\right)_{2} \mathrm{FO}_{2}$ & -0.89 & -1.37 & -0.71 & 1.95 \\
$\mathrm{Na}_{3} \mathrm{~V}_{2}\left(\mathrm{PO}_{4}\right)_{2} \mathrm{~F}_{3}$ & -0.70 & -1.39 & -0.77 & 1.87 \\
$\mathrm{NaV}_{2}\left(\mathrm{PO}_{4}\right)_{2} \mathrm{FO}_{2}$ & -0.60 & -1.26 & -0.68 & 2.03 \\
$\mathrm{NaV}_{2}\left(\mathrm{PO}_{4}\right)_{2} \mathrm{~F}_{3}$ & -0.62 & -1.27 & -0.61 & 2.02 \\
\hline
\end{tabular}

partial charge on $\mathrm{V}$ is similar for $\mathrm{Na}_{3} \mathrm{~V}_{2}\left(\mathrm{PO}_{4}\right)_{2} \mathrm{FO}_{2}$ and $\mathrm{Na}_{3} \mathrm{~V}_{2}\left(\mathrm{PO}_{4}\right)_{2} \mathrm{~F}_{3}$, and becomes even closer when two $\mathrm{Na}$ are extracted. We note, however, that the charge associated with the $\mathrm{V}$ couple is delocalized from the $\mathrm{V}$ center, and so the Bader charge on $\mathrm{V}$ can only provide a relative, and not an absolute measure of the $\mathrm{V}$ charge state as $\mathrm{V}^{\mathrm{III}}$ or $\mathrm{V}^{\mathrm{IV}}$. The reason that the charge state of $\mathrm{V}$ can be the same despite the different formal charges of $\mathrm{O}$ and $\mathrm{F}$ is that in $\mathrm{Na}_{3} \mathrm{~V}_{2}\left(\mathrm{PO}_{4}\right)_{2} \mathrm{FO}_{2}$ and $\mathrm{NaV}_{2}\left(\mathrm{PO}_{4}\right)_{2} \mathrm{FO}_{2}$ the negative charge of the dangling $\mathrm{O}$ is significantly less than $\mathrm{O}$ in $\mathrm{PO}_{4}$, and is similar to that of $\mathrm{F}$. The actual charge state of the dangling $\mathrm{O}$ is closer to $\mathrm{O}^{-}$than $\mathrm{O}^{2-}$. Additional evidence for having the same redox couple in the two materials is provided by the calculated densities of states in Figure 8. States near the Fermi level are of $\mathrm{V}$ character mixed

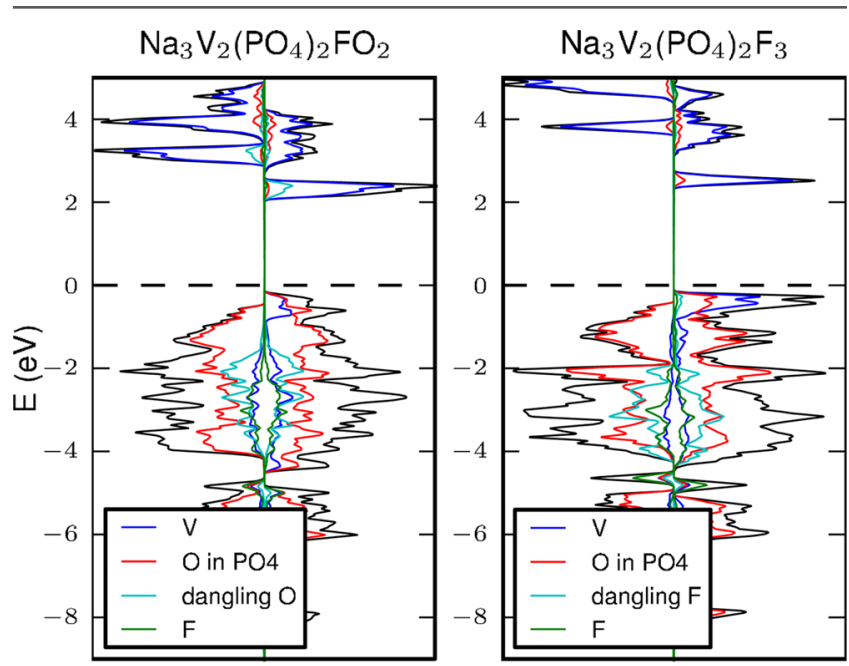

Density of states $N(E)$

Figure 8. Comparison of the density of states between $\mathrm{Na}_{3} \mathrm{~V}_{2}\left(\mathrm{PO}_{4}\right)_{2} \mathrm{FO}_{2}$ and $\mathrm{Na}_{3} \mathrm{~V}_{2}\left(\mathrm{PO}_{4}\right)_{2} \mathrm{~F}_{3}$.

with $\mathrm{O}$ from the $\mathrm{PO}_{4}$ groups. The energy level and the shape of this band, which make up the $\mathrm{V}$ redox couple at the Fermi level, are very similar for the two materials. The states from the dangling $\mathrm{O} / \mathrm{F}$ are about $2 \mathrm{eV}$ lower than those of the $\mathrm{O}$ in $\mathrm{PO}_{4}$, and are largely isolated from the redox couple. One can also see a hole localized on the dangling $\mathrm{O}$ in the DOS of $\mathrm{Na}_{3} \mathrm{~V}_{2}\left(\mathrm{PO}_{4}\right)_{2} \mathrm{FO}_{2}$, which is not present on the dangling $\mathrm{F}$ in $\mathrm{Na}_{3} \mathrm{~V}_{2}\left(\mathrm{PO}_{4}\right)_{2} \mathrm{~F}_{3}$, which supports the $\mathrm{O}^{-}$assignment from our charge density analysis. The main result is that the electronic structure of these two materials are similar, and the depletion of electrons during charging is not localized at V centers, as in the traditional view of a fixed redox couple energy.

Since the calculations are able to reproduce the measured voltages, we can then use computational experiments to reduce the $\mathrm{Na}$ binding in the $x<1$ phase. One strategy is to replace the bridging $\mathrm{F}$ in $\mathrm{Na}_{x} \mathrm{~V}_{2}\left(\mathrm{PO}_{4}\right)_{2} \mathrm{FO}_{2}$ with a less electronegative ion, such as $\mathrm{Cl}$ or Br. As shown in Figure 9, the first plateau drops to

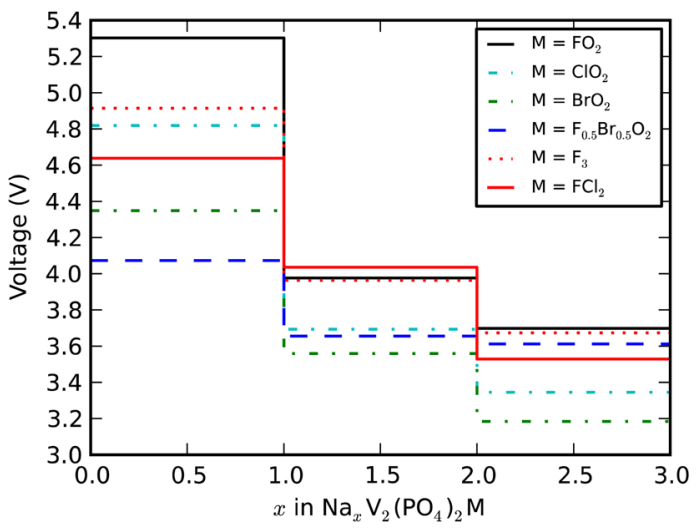

Figure 9. Comparison of the voltage profiles of $\mathrm{Na}_{x} \mathrm{~V}_{2}\left(\mathrm{PO}_{4}\right)_{2} \mathrm{M}$ with different anion $(\mathrm{M})$ substitutions.

4.8 $\mathrm{V}$ and the other two plateaus drop by $0.3 \mathrm{~V}$ with $\mathrm{Cl}$ substitution, making it just possible to extract the final $\mathrm{Na}$ ion and realize the extra capacity at $4.8 \mathrm{~V}$ for $\mathrm{ClO}_{2}$, within the electrolyte stability window. With $\mathrm{Br}$ substitution, the first plateau drops to $4.4 \mathrm{~V}$, which is safe for common electrolytes. However, the other two (lower voltage) plateaus are also reduced by about $0.5 \mathrm{~V}$, which would significantly decrease the energy density. The $\mathrm{F}_{0.5} \mathrm{Br}_{0.5} \mathrm{O}_{2}$ compound gives the most desirable voltage profile (Figure 9, dashed blue line). Unlike $\mathrm{F}_{0.5} \mathrm{Cl}_{0.5} \mathrm{O}_{2}$, where the plateau at $0<x<1$ is between those of $\mathrm{ClO}_{2}$ and $\mathrm{FO}_{2}, \mathrm{~F}_{0.5} \mathrm{Br}_{0.5} \mathrm{O}_{2}$ results in a remarkably low first plateau at $4.1 \mathrm{~V}$, one that is even lower than with $\mathrm{BrO}_{2}$. The other two plateaus $(1<x<2$ and $2<x<3)$ are higher than that of $\mathrm{BrO}_{2}$, as expected, and both are close to $3.6 \mathrm{~V}$ giving a high energy density of $684 \mathrm{Wh} \mathrm{kg}^{-1}$.

Side views of the structures at $x=1$ and 3 with $\mathrm{M}=$ $\mathrm{F}_{0.5} \mathrm{Br}_{0.5} \mathrm{O}_{2}$ are shown in Figure 10. The distortion of the structure at $x=1$ reflects the difference of anion radii. At $x=3$, the distortion is reduced as well as the voltage drop. While these predictions are encouraging, the difficulties associated with the synthesis of such a Br-substituted material may be prohibitive. $\mathrm{Br}$ escaping the half-substituted material is slightly energetically favorable, as calculated by eq 3 . The halfsubstituted structure, however, is metastable and could, potentially, be synthesized.

$$
\begin{aligned}
& \left(\mathrm{Na}_{3} \mathrm{~V}_{2}\left(\mathrm{PO}_{4}\right)_{2} \mathrm{ClO}_{2}\right) \times 8=\left(\mathrm{Na}_{3} \mathrm{~V}_{2}\left(\mathrm{PO}_{4}\right)_{2} \mathrm{Cl}_{0.875} \mathrm{O}_{2}\right) \times 8 \\
& \quad+\frac{1}{2} \mathrm{Cl}_{2} \quad \Delta E=1.58 \mathrm{eV} \\
& \left(\mathrm{Na}_{3} \mathrm{~V}_{2}\left(\mathrm{PO}_{4}\right)_{2} \mathrm{BrO}_{2}\right) \times 8=\left(\mathrm{Na}_{3} \mathrm{~V}_{2}\left(\mathrm{PO}_{4}\right)_{2} \mathrm{Br}_{0.875} \mathrm{O}_{2}\right) \times 8 \\
& \quad+\frac{1}{2} \mathrm{Br}_{2} \quad \Delta E=0.90 \mathrm{eV}
\end{aligned}
$$



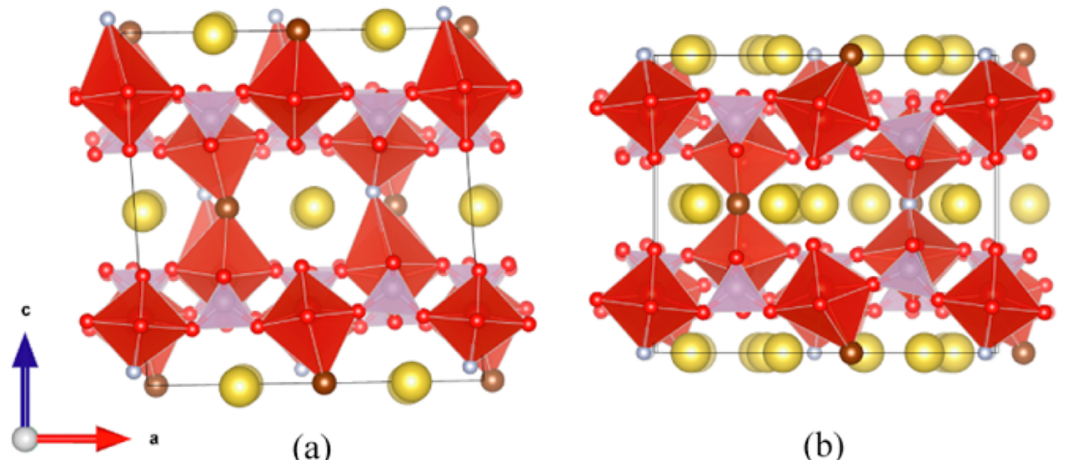

(b)

Figure 10. Structures of (a) $\mathrm{NaV}_{2}\left(\mathrm{PO}_{4}\right)_{2} \mathrm{~F}_{0.5} \mathrm{Br}_{0.5} \mathrm{O}_{2}$ and (b) $\mathrm{Na}_{3} \mathrm{~V}_{2}\left(\mathrm{PO}_{4}\right)_{2} \mathrm{~F}_{0.5} \mathrm{Br}_{0.5} \mathrm{O}_{2}$. The brown atoms are $\mathrm{Br}$.

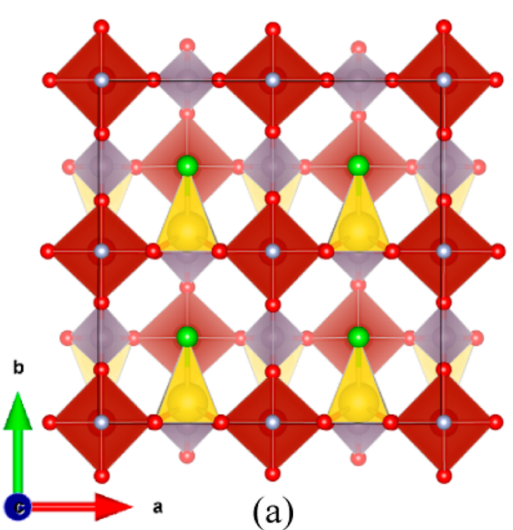

(a)

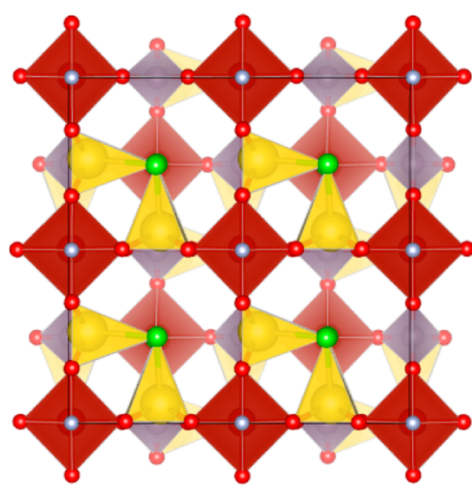

(b)

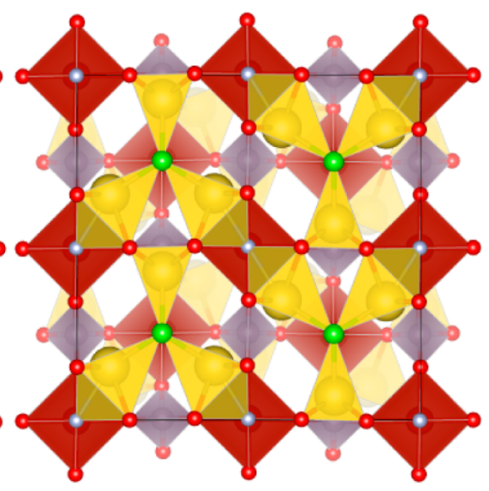

(c)

Figure 11. Structures of (a) $\mathrm{NaV}_{2}\left(\mathrm{PO}_{4}\right)_{2} \mathrm{FCl}_{2}$, (b) $\mathrm{Na}_{2} \mathrm{~V}_{2}\left(\mathrm{PO}_{4}\right)_{2} \mathrm{FCl}_{2}$, (c) $\mathrm{Na}_{3} \mathrm{~V}_{2}\left(\mathrm{PO}_{4}\right)_{2} \mathrm{FCl}_{2}$. The green atoms are $\mathrm{Cl}$.

$$
\begin{aligned}
& \left(\mathrm{Na}_{3} \mathrm{~V}_{2}\left(\mathrm{PO}_{4}\right)_{2} \mathrm{~F}_{0.5} \mathrm{Br}_{0.5} \mathrm{O}_{2}\right) \times 8=\left(\mathrm{Na}_{3} \mathrm{~V}_{2}\right. \\
& \left.\quad\left(\mathrm{PO}_{4}\right)_{2} \mathrm{~F}_{0.5} \mathrm{Br}_{0.375} \mathrm{O}_{2}\right) \times 8+\frac{1}{2} \mathrm{Br}_{2} \quad \Delta E=-0.21 \mathrm{eV}
\end{aligned}
$$

In the transition from $\mathrm{Na}_{3} \mathrm{~V}_{2}\left(\mathrm{PO}_{4}\right)_{2} \mathrm{FO}_{2}$ to $\mathrm{Na}_{3} \mathrm{~V}_{2}\left(\mathrm{PO}_{4}\right)_{2} \mathrm{~F}_{3}$, the two $\mathrm{O}$ are replaced by $\mathrm{F}$. Inspired by this strategy, we try occupying the oxygen sites with $\mathrm{Cl}$ instead of $\mathrm{F}$ to form $\mathrm{Na}_{3} \mathrm{~V}_{2}\left(\mathrm{PO}_{4}\right)_{2} \mathrm{FCl}_{2}$. Compared to $\mathrm{F}, \mathrm{Cl}$ is less electronegative and thus attracts less negative charge and reduces the binding to the positive $\mathrm{Na}$ ions. The relative binding energies at the P1 and $\mathrm{P} 2$ sites reverse in response to this substitution. The $\mathrm{P} 2$ site is more stable by $0.08 \mathrm{eV}$ than the $\mathrm{P} 1$ site; and as a result, $\mathrm{Na}$ atoms order in different patterns, as shown in Figure 11. The voltage profile of $\mathrm{Na}_{3} \mathrm{~V}_{2}\left(\mathrm{PO}_{4}\right)_{2} \mathrm{FCl}_{2}$ (solid red line in Figure 9) looks even better than that of $\mathrm{F}_{0.5} \mathrm{Br}_{0.5} \mathrm{O}_{2}$; the average voltage of the three plateaus is higher and the highest one is well within the stable electrolyte voltage window. The capacity of $\mathrm{Na}_{3} \mathrm{~V}_{2}\left(\mathrm{PO}_{4}\right)_{2} \mathrm{FCl}_{2}$ with all three $\mathrm{Na}$ being accessible is 188 $\mathrm{mAh} \mathrm{g}^{-1}$, and the corresponding energy density is $758 \mathrm{Wh}$ $\mathrm{kg}^{-1}$. Another advantage to substitution at the $\mathrm{O}$ site is that it has little influence on the framework so that the structure is more likely to be synthesized. The stability of $\mathrm{Na}_{3} \mathrm{~V}_{2}\left(\mathrm{PO}_{4}\right)_{2} \mathrm{FCl}_{2}$ is tested computationally by considering three decomposition scenarios. Equation 4 describes $\mathrm{Cl}$ escaping as $\mathrm{Cl}_{2}$ leaving vacancies behind; eq 5 describes $\mathrm{Cl}$ being substituted by $\mathrm{O}$ from water. Both of these are energetically unfavorable. The last test, considering anion disorder, involves the swap of one $\mathrm{F}$ with $\mathrm{Cl}$ in eight formula units, leaving the stoichiometry fixed, which results in a $0.54 \mathrm{eV}$ energy rise. This observation means that $\mathrm{F}-\mathrm{Cl}$ disorder is not expected when the $\mathrm{Cl} / \mathrm{F}$ ratio is set to 2 . The reverse reaction of eq 5 is a possible approach to synthesize $\mathrm{Na}_{3} \mathrm{~V}_{2}\left(\mathrm{PO}_{4}\right)_{2} \mathrm{FCl}_{2}$.

$$
\begin{aligned}
& \left(\mathrm{Na}_{3} \mathrm{~V}_{2}\left(\mathrm{PO}_{4}\right)_{2} \mathrm{FCl}_{2}\right) \times 8=\left(\mathrm{Na}_{3} \mathrm{~V}_{2}\left(\mathrm{PO}_{4}\right)_{2} \mathrm{FCl}_{1.875}\right) \times 8 \\
& \quad+\frac{1}{2} \mathrm{Cl}_{2} \quad \Delta E=2.23 \mathrm{eV} \\
& \mathrm{Na}_{3} \mathrm{~V}_{2}\left(\mathrm{PO}_{4}\right)_{2} \mathrm{FCl}_{2}+2 \mathrm{H}_{2} \mathrm{O}=\mathrm{Na}_{3} \mathrm{~V}_{2}\left(\mathrm{PO}_{4}\right)_{2} \mathrm{FO}_{2}+2 \mathrm{HCl} \\
& \quad+\mathrm{H}_{2} \quad \Delta E=2.30 \mathrm{eV}
\end{aligned}
$$

Next, we calculated the stabilities of these compounds during cycling. Fully charged $\mathrm{Na}_{3} \mathrm{~V}_{2}\left(\mathrm{PO}_{4}\right)_{2} \mathrm{FCl}_{2}$ turns out to be stable

$$
\begin{aligned}
& \left(\mathrm{V}_{2}\left(\mathrm{PO}_{4}\right)_{2} \mathrm{FCl}_{2}\right) \times 8=\left(\mathrm{V}_{2}\left(\mathrm{PO}_{4}\right)_{2} \mathrm{FCl}_{1.875}\right) \times 8+\frac{1}{2} \mathrm{Cl}_{2} \\
& \Delta E=0.20 \mathrm{eV} \\
& \left(\mathrm{V}_{2}\left(\mathrm{PO}_{4}\right)_{2} \mathrm{FCl}_{2}\right) \times 8=\left(\mathrm{V}_{2} \mathrm{P}_{2} \mathrm{O}_{7.875} \mathrm{FCl}_{2}\right) \times 8+\frac{1}{2} \mathrm{O}_{2} \\
& \Delta E=3.35 \mathrm{eV}
\end{aligned}
$$

while $\mathrm{O}_{2}$ evolution is spontaneous when $\mathrm{Na}_{3} \mathrm{~V}_{2}\left(\mathrm{PO}_{4}\right)_{2} \mathrm{FO}_{2}$ is fully charged

$$
\begin{aligned}
& \left(\mathrm{V}_{2}\left(\mathrm{PO}_{4}\right)_{2} \mathrm{FO}_{2}\right) \times 8=\left(\mathrm{V}_{2}\left(\mathrm{PO}_{4}\right)_{2} \mathrm{FO}_{1.875}\right) \times 8+\frac{1}{2} \mathrm{O}_{2} \\
& \Delta E=-0.30 \mathrm{eV}
\end{aligned}
$$

Finally, we consider the replacement of $\mathrm{Na}$ with $\mathrm{Li}$ so that the material can be used in a Li cell. Due to the strong binding of the last $\mathrm{Na}$, only two $\mathrm{Na}$ per formula can be substituted by Li. This result is understood both from calculations and 


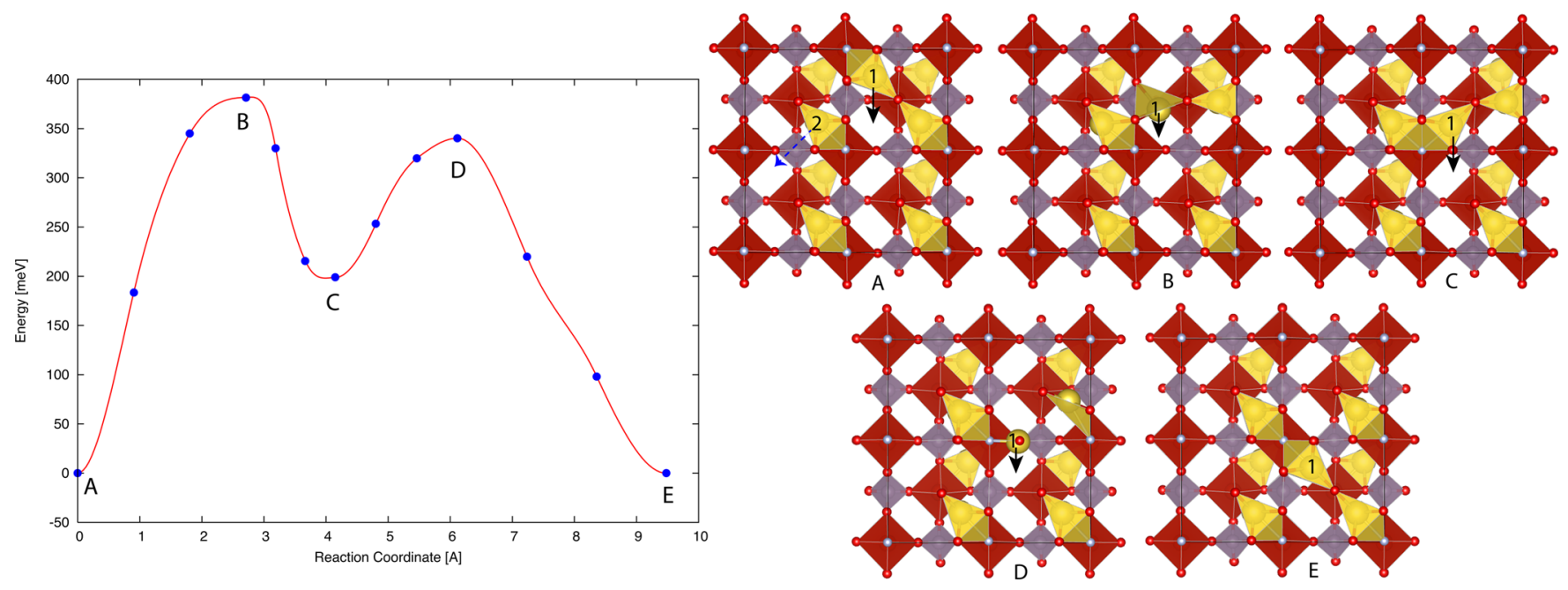

Figure 12. Minimum energy path of $\mathrm{Na}$ diffusion in $\mathrm{Na}_{1.125} \mathrm{~V}_{2}\left(\mathrm{PO}_{4}\right) \mathrm{FO}_{2}$.
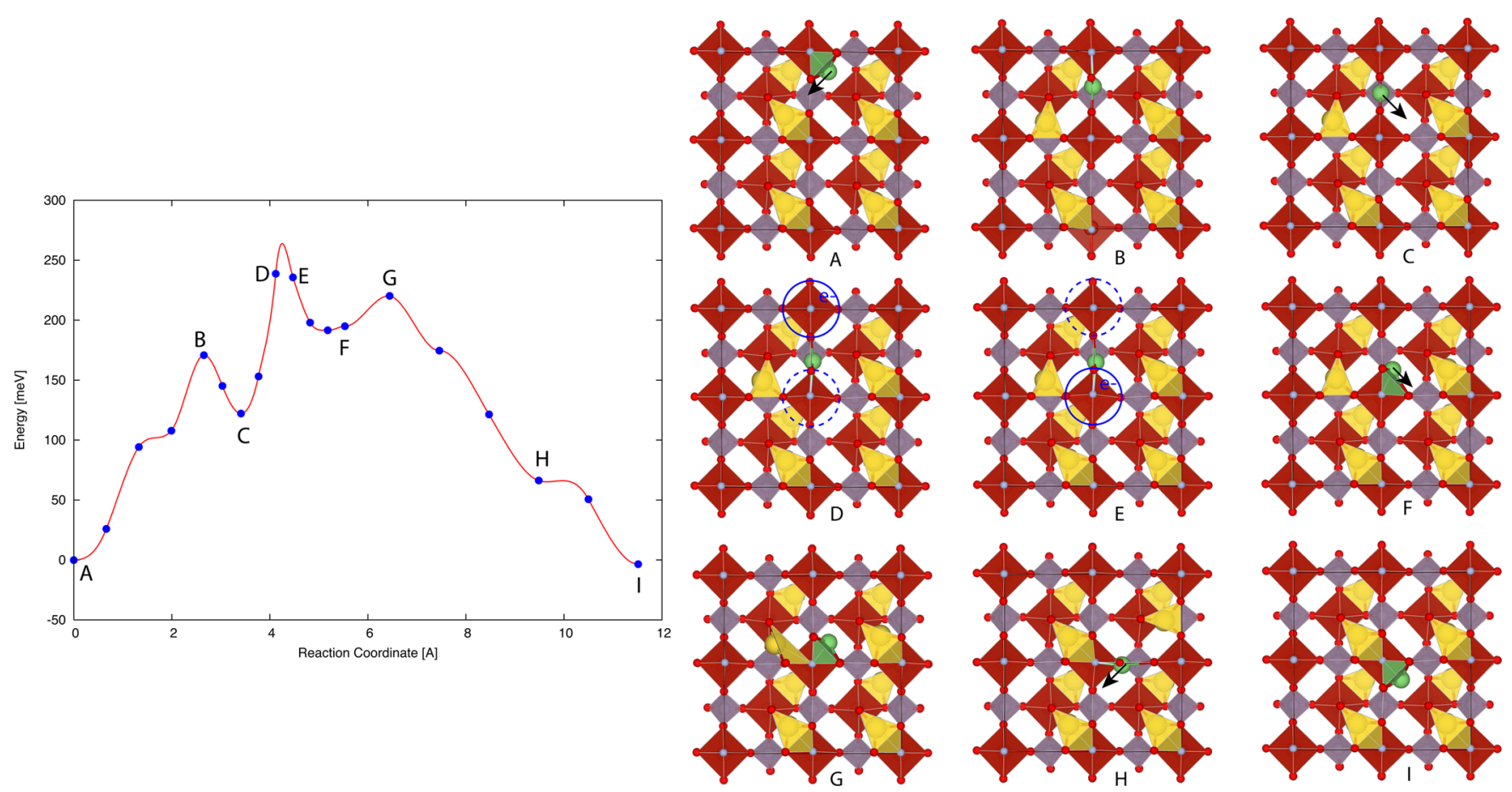

Figure 13. Minimum energy path for $\mathrm{Li}$ diffusion in $\mathrm{NaLi}_{0.125} \mathrm{~V}_{2}\left(\mathrm{PO}_{4}\right) \mathrm{FO}_{2}$. $\mathrm{Li}$ is colored green.

observed in our experiment, as well as in Park's report. ${ }^{13}$ The energy difference to replace two $\mathrm{Na}$ with $\mathrm{Li}$ is $-0.079 \mathrm{eV}$; this result indicates that the reaction occurs spontaneously. The energy difference to substitute the last $\mathrm{Na}$ with $\mathrm{Li}$ (as in eq 6) is $0.073 \mathrm{eV}$, so that it will not happen spontaneously.

$$
\begin{aligned}
& \mathrm{Na}_{3} \mathrm{~V}_{2}\left(\mathrm{PO}_{4}\right)_{2} \mathrm{FO}_{2}+2 \mathrm{Li}=\mathrm{NaLi}_{2} \mathrm{~V}_{2}\left(\mathrm{PO}_{4}\right)_{2} \mathrm{FO}_{2}+2 \mathrm{Na} \\
& \Delta E=-0.079 \mathrm{eV} \\
& \mathrm{NaLi}_{2} \mathrm{~V}_{2}\left(\mathrm{PO}_{4}\right)_{2} \mathrm{FO}_{2}+\mathrm{Li}=\mathrm{Li}_{3} \mathrm{~V}_{2}\left(\mathrm{PO}_{4}\right)_{2} \mathrm{FO}_{2}+\mathrm{Na} \\
& \Delta E=0.073 \mathrm{eV}
\end{aligned}
$$

In order to determine the lowest energy structures containing $\mathrm{Li}$, we used the basin-hopping algorithm ${ }^{20}$ with one $\mathrm{Na}$ in the formula unit as $\mathrm{NaLi}_{x-1} \mathrm{~V}_{2}\left(\mathrm{PO}_{4}\right) \mathrm{FO}_{2}(1<x<3)$. The voltage profile of $\mathrm{Li}$ is plotted in Figure $7 \mathrm{~b}$. The first plateau $(2<x<3)$ matches the experimental value, while the second one $(1<x<2)$ is lower by $0.2 \mathrm{~V}$. The deviation might be due to subtle structural changes caused by the ion exchange.

Finally, $\mathrm{Li} / \mathrm{Na}$ diffusion is studied by calculating the minimum energy paths for ion hopping with the nudged elastic band method. ${ }^{18,19}$ Since one Na is always trapped inside the material, one extra $\mathrm{Na} / \mathrm{Li}$ atom is added to the structure (Figure 6b) to form $\mathrm{Na}_{1.125} \mathrm{~V}_{2}\left(\mathrm{PO}_{4}\right) \mathrm{FO}_{2}$ or $\mathrm{NaLi}_{0.125} \mathrm{~V}_{2}\left(\mathrm{PO}_{4}\right)$ $\mathrm{FO}_{2}$. The motion of this extra atom is investigated to calculate the diffusion barrier. Since $\mathrm{NaV}_{2}\left(\mathrm{PO}_{4}\right) \mathrm{FO}_{2}$ and $\mathrm{Na}_{2} \mathrm{~V}_{2}\left(\mathrm{PO}_{4}\right)$ $\mathrm{FO}_{2}$ form the two phases on the convex hull, $\mathrm{Na}_{1.125} \mathrm{~V}_{2}\left(\mathrm{PO}_{4}\right)$ $\mathrm{FO}_{2}$ represents a $\mathrm{Na}$ concentration at the transition between these two phases. The minimum energy path for $\mathrm{Na}$ diffusion in $\mathrm{Na}_{1.125} \mathrm{~V}_{2}\left(\mathrm{PO}_{4}\right) \mathrm{FO}_{2}$ is shown in Figure 12. As $\mathrm{Nal}$ diffuses (downward in the figure), it repels the nearby Na3. The resulting diffusion path has a barrier of $0.37 \mathrm{eV}$, higher than the $0.3 \mathrm{eV}$ diffusion barrier in the dilute limit due to the $\mathrm{Na}-\mathrm{Na}$ 
interactions. Another possible path has $\mathrm{Na} 2$ moving along the blue dashed line with $\mathrm{Nal}$ following, which is similar to the path calculated in ref 13 . This second path suffers from a stronger $\mathrm{Na}-\mathrm{Na}$ repulsion, and the overall barrier is $0.55 \mathrm{eV}$.

The Li diffusion mechanism, shown in Figure 13, has a barrier of $0.27 \mathrm{eV}$; lower than for $\mathrm{Na}$ diffusion. Along the path, $\mathrm{Li}$ goes through a high-energy site with four coordinating oxygen atoms (Figure 13C). From configuration D to E, the $\mathrm{Li}$ position remains constant, and a polaron (blue circle) hops from the upper $\mathrm{V}$ to the lower one. The charge transfer between the $\mathrm{V}$ centers can be clearly seen from the change in $\mathrm{V}$ onsite occupancies, calculated in the DFT $+\mathrm{U}$ framework. Interestingly, the charge transfer results in a curve crossing on the minimum energy path, instead of a saddle point. Another interesting feature is that, owing to its smaller size, $\mathrm{Li}$ diffuses via a zigzag path to be better coordinated by $\mathrm{O}$, whereas the Na path is relatively straight. The lower diffusion barrier for Li diffusion explains the better rate performance of the Li battery, as is observed in our experiment.

\section{CONCLUSION}

In summary, simple and environmentally friendly solvothermal methods provide easy routes to the synthesis of $\mathrm{Na}_{3} \mathrm{~V}_{2} \mathrm{O}_{2}\left(\mathrm{PO}_{4}\right)_{2} \mathrm{~F}$ and then $\mathrm{Na}_{3-x} \mathrm{Li}_{x} \mathrm{~V}_{2} \mathrm{O}_{2}\left(\mathrm{PO}_{4}\right)_{2} \mathrm{~F}$ by ion exchange. Through first-principle calculations, we have explained the two plateaus in the voltage profiles of $\mathrm{Na}_{3} \mathrm{~V}_{2} \mathrm{O}_{2}\left(\mathrm{PO}_{4}\right)_{2} \mathrm{~F} / \mathrm{Na}$ and why the third $\mathrm{Na}$ is difficult to extract either electrochemically or by chemical ion exchange. We find a possible approach to access the third $\mathrm{Na}$ per formula unit is to substitute $\mathrm{O}$ with $\mathrm{Cl}$ to form $\mathrm{Na}_{3} \mathrm{~V}_{2} \mathrm{Cl}_{2}\left(\mathrm{PO}_{4}\right)_{2} \mathrm{~F}$. The energy density of the new compound with three active $\mathrm{Na}$ increases to $758 \mathrm{Wh} \mathrm{kg}^{-1}$. This compound is calculated to be stable on removal of all the $\mathrm{Na}$ and possible to synthesize. Finally, we show that $\mathrm{Na}_{3-x} \mathrm{Li}_{x} \mathrm{~V}_{2} \mathrm{O}_{2}\left(\mathrm{PO}_{4}\right)_{2} \mathrm{~F}$ can also be used as a cathode in a $\mathrm{Li}$ ion cell with an even higher rate capability.

\section{EXPERIMENTAL METHODS}

The synthesis was started with a solution made from $0.001 \mathrm{~mol}$ of $\mathrm{NH}_{4} \mathrm{VO}_{3}$ and $0.0015 \mathrm{~mol}$ of $\mathrm{NaF}$ dissolved in $10 \mathrm{~mL}$ of deionized water. Then, $0.001 \mathrm{~mol}\left(\mathrm{NH}_{4}\right)_{2} \mathrm{HPO}_{4}$ was dissolved in another beaker with $10 \mathrm{~mL}$ of deionized water and slowly added to the above solution to keep the molar ratio Na:V:P:F = 3:2:2:3, after which $10 \mathrm{~mL}$ of $N, N$ Dimethylformamide (DMF) was added. This solution was transferred into two separate $40 \mathrm{~mL}$ Teflon autoclaves. Solvothermal treatment was conducted at $180{ }^{\circ} \mathrm{C}$ for $24 \mathrm{~h}$ to obtain the final product. After each treatment, the sample was removed by filtration; the product was washed with distilled water and dehydrated alcohol before drying in air at $120{ }^{\circ} \mathrm{C}$ overnight. To prepare the isostructural lithium derivative of $\mathrm{Na}_{3} \mathrm{~V}_{2} \mathrm{O}_{2}\left(\mathrm{PO}_{4}\right)_{2} \mathrm{~F}$, we performed $\mathrm{Na} / \mathrm{Li}$ ion exchange in 1-hexanol (Sigma-Aldrich, 99\%) at its boiling point (ca. $160{ }^{\circ} \mathrm{C}$ ) under reflux. $\mathrm{LiBr}$ (Sigma-Aldrich, 99\%) was used as the lithium source. An excess amount (20 times) of $\mathrm{LiBr}$ was added prior to the reaction, and the volume of the solvent (i.e., 1-hexanol) was adjusted to make a $10 \mathrm{M}$ $\mathrm{LiBr}$ solution. After reacting for $12 \mathrm{~h}$, the product was washed, centrifuged several times with the same solvent, and then completely dried in a vacuum oven at $80{ }^{\circ} \mathrm{C}$ overnight, resulting in a greencolored $\mathrm{Na}_{3-x} \mathrm{Li}_{x} \mathrm{~V}_{2} \mathrm{O}_{2}\left(\mathrm{PO}_{4}\right)_{2} \mathrm{~F}$ powder.

Characterization. X-ray powder diffraction (XRD) patterns for each sample were recorded with a Philips X-ray diffractometer and $\mathrm{Cu}$ $\mathrm{K} \alpha$ radiation over the $2 \theta$ range $5^{\circ}-80^{\circ}$. Scanning electron microscopy (SEM) was performed with a Quanta 650 scanning electron microscope.

Electrode Fabrication and Electrochemical Tests. The electrochemical performance of each sample was evaluated with a standard CR2032 coin cell composed of the cathode, a sodium anode, and a Celgrade polypropylene separator. $\mathrm{Na}_{3} \mathrm{~V}_{2} \mathrm{O}_{2}\left(\mathrm{PO}_{4}\right)_{2} \mathrm{~F}$ as sodium ion cathode material was tested in electrolyte $\left(1 \mathrm{M} \mathrm{NaPF}_{6}\right.$ solution) in a mixture of ethyl carbonate/dimethyl carbonate (EC/DMC, 1:1 v/v); $\mathrm{Na}_{3-x} \mathrm{Li}_{x} \mathrm{~V}_{2} \mathrm{O}_{2}\left(\mathrm{PO}_{4}\right)_{2} \mathrm{~F}$ as $\mathrm{Li}$ ion cathode material was tested in electrolyte $\left(1 \mathrm{M} \mathrm{LiPF}_{6}\right.$ solution) in a mixture of ethyl carbonate/ dimethyl carbonate $(\mathrm{EC} / \mathrm{DMC}, 1: 1 \mathrm{v} / \mathrm{v})$. To prepare the cathode layer, a slurry was made by mixing the $\mathrm{Na}_{3} \mathrm{~V}_{2} \mathrm{O}_{2}\left(\mathrm{PO}_{4}\right)_{2} \mathrm{~F}$ active material with carbon black (Alfa Aesar) and poly(vinylidene fluoride) (PVdF) in $\mathrm{N}$-methyl-2-pyrrolidone (NMP) with a weight ratio of $75: 20: 5$. The suspensions were spread on an aluminum current collector with a doctor blade. After the evaporation of the solvent in an oven at $80{ }^{\circ} \mathrm{C}$ for $12 \mathrm{~h}$, the samples were punched into circular disks $0.78 \mathrm{~cm}$ in diameter. The loading of the active material was about $1-2$ $\mathrm{mg} \mathrm{cm}{ }^{-2}$. All cells were fabricated in an argon-filled glovebox. The cells were aged for $2 \mathrm{~h}$ before charge/discharge to ensure full absorption of the electrolyte into the electrode. Initially, cells were galvanostatically cycled at a low current density of $6.5 \mathrm{~mA} \mathrm{~g}^{-1}$ (about C/20 rate) in a Land Instruments testing system.

Theoretical Methods. Global minima of $\mathrm{Na}_{x} \mathrm{~V}_{2}\left(\mathrm{PO}_{4}\right)_{2} \mathrm{FO}_{2}$ for $x=$ $0.125,1.0,1.5,2.0,2.53 .0$ were found with the basin-hopping algorithm. ${ }^{20}$ Each move consisted of randomly swapping the position of a $\mathrm{Na}$ atom to the position of a vacancy site. The geometry of the trial configuration was optimized by DFT calculations, and with the resultant energy, the trial configuration was either accepted or rejected. For each possible value of $x$ (given the small unit cell) in $\mathrm{Na}_{x} \mathrm{~V}_{2}\left(\mathrm{PO}_{4}\right)_{2} \mathrm{FO}_{2}$, hundreds of local minima of $\mathrm{Na}$ arrangements were sampled.

Geometric relaxation was completed by DFT calculations with corrections for on-site Coulomb interactions of transition metals $(\mathrm{DFT}+\mathrm{U})$ using the Vienna ab initio simulation package. ${ }^{21}$ The generalized gradient approximation with PW91 functional was chosen to describe electron exchange and correlation. ${ }^{22}$ All calculations included spin polarization. Core electrons were incorporated into pseudopotentials with the projector augmented wave method, and valence electrons were described with a plane-wave basis set. ${ }^{2,24}$ Relaxations during basin-hopping searches were calculated with an energy cutoff of $256 \mathrm{eV}$; a higher cutoff of $333 \mathrm{eV}$ was used for relaxation of the global minima for the convex hull construct. A Monkhorst-Pack $k$-point mesh of $1 \times 1 \times 1$ was used during search relaxations and $3 \times 3 \times 2$ for final relaxations. An on-site Hubbard term $(U)$ was used for the transition metal, $\mathrm{V}$, to avoid artificial delocalization of $3 \mathrm{~d}$ electrons as a result of self-interaction. ${ }^{25}$ The effective $U$ value $\left(U_{\text {eff }}=U-J\right)$ was taken from the literature, $U_{\text {eff }}=$ $4.0 .^{26}$

\section{AUTHOR INFORMATION}

\section{Corresponding Author}

*E-mail: henkelman@cm.utexas.edu, jgoodenough@mail. utexas.edu. Phone: 01-512-471-4179, 01-512-471-1646. Fax: 01-512-471-8696, 01-512-471-7681.

\section{Author Contributions}

"M.X. and P.X. equally contributed to the paper: M.X. did the experimental work and P.X. contributed the theoretical calculations. J.B.G. and G.H. interpreted the results and were responsible for the write up.

\section{Notes}

The authors declare no competing financial interest.

\section{ACKNOWLEDGMENTS}

This work is supported by the Department of Energy Office of Basic Energy Science grant (No. DE-SC0005397) and the Energy Frontier Research Center "Understanding Charge Separation and Transfer at Interfaces in Energy Materials (EFRC:CST)" (No. DE-SC0001091), The Robert A Welch Foundation, Houston, Texas Grant numbers F-1066 and F1841, the Fundamental Research Funds for the Central Universities (Nos. SWU113079, XDJK2014C051) and the 
National Natural Science Foundation of China (No. 21063014). Calculations were done with resources from the National Energy Research Scientific Computing Center and the Texas Advanced Computing Center.

\section{REFERENCES}

(1) Goodenough, J. B. J. Solid State Electrochem. 2012, 16, 20192029.

(2) Lu, Y.; Wang, L.; Cheng, J. G.; Goodenough, J. B. Chem. Commun. 2012, 48, 6544-6546.

(3) Wurm, C.; Goward, G.; Masquelier, C.; Nazar, L. F. Chem. Mater. 2000, 12, 3240-3242.

(4) Komaba, S.; Murata, W.; Ishikawa, T.; Yabuuchi, N.; Ozeki, T.; Nakayama, T.; Ogata, A.; Gotoh, K.; Fujiwara, K. Adv. Funct. Mater. 2011, 21, 3859-3867.

(5) Ellis, B. L.; Nazar, L. F. Curr. Opin. Solid State Mater. Sci. 2012, 16, 168-177.

(6) Palomares, V.; Serras, P.; Villaluenga, I.; Hueso, K. B.; CarreteroGonzález, J.; Rojo, T. Energy Environ. Sci. 2012, 5, 5884-5901.

(7) Serras, P.; Palomares, V.; Kubiak, P.; Lezama, L.; Rojo, T. Electrochem. Commun. 2013, 34, 344-347.

(8) Chevrier, V. L.; Ceder, G. J. Electrochem. Soc. 2011, 158 (9), 1011-1014.

(9) Ellis, B. L.; Michael, W. R.; Makahnouk, W. R. M.; RowanWeetaluktuk, W. N.; Ryan, D. H.; Nazar, L. F. Chem. Mater. 2010, 22, $1059-1070$

(10) Sauvage, F.; Quarez, E.; Tarascon, J.-M.; Bausrin, E. Solid State Sci. 2006, 8, 1215-1221.

(11) Gover, R. K. B.; Bryan, A. J.; Burns, P.; Barker, J. Solid State Ionics 2006, 177, 1495-1500.

(12) Barker, J.; Gover, R. K. B.; Burns, P.; Bryan, A. J. J. Electrochem. Soc. 2007, 154, 882-887.

(13) Park, Y.; Seo, D.; Kim, B.; Hong, K.; Kim, H.; Lee, S.; Shakoor, R. A.; Miyasaka, K.; Tarascon, J. M.; Kang, K. Sci. Rep. 2012, $2,704$.

(14) Serras, P.; Palomares, V.; Goñi, A.; Kubiak, P.; Rojo, T. J. Power Sources 2013, 241, 56-60.

(15) Liao, Y. H.; Park, K. S.; Xiao, P.; Henkelman, G.; Li, W.; Goodenough, J. B. Chem. Mater. 2013, 25, 1699-1705.

(16) Shakoor, R. A.; Seo, D. H.; Kim, H.; Park, Y.; Kim, J.; Kim, S. W.; Gwon, H.; Lee, S.; Kang, K. J. Mater. Chem. 2012, 22, 2053520541.

(17) Chihara, K.; Kitajou, A.; Gocheva, I. D.; Okada, S.; Yamaki, J. J. Power Sources 2013, 227, 80-85.

(18) Henkelman, G.; Jónsson, H. J. Chem. Phys. 2000, 113, 99789985.

(19) Henkelman, G.; Uberuaga, B. P.; Jónsson, H. J. Chem. Phys. 2000, 113, 9901-9904.

(20) Wales, D. J.; Doye, J. P. K. J. Phys. Chem. A 1997, 101, 51115116.

(21) Kohn, W.; Becke, A. D.; Parr, R. G. J. Phys. Chem. 1996, 100, 12974-12980.

(22) Perdew, J. P.; Wang, Y. Phys. Rev. B 1992, 45, 13244-13249.

(23) Blochl, P. E. Phys. Rev. B 1994, 50, 17953-17978.

(24) Kresse, G.; Joubert, J. Phys. Rev. B 1999, 59, 1758-1775.

(25) Dudarev, S. L.; Botton, G. A.; Savrasov, S. Y.; Humphreys, C. J.; Sutton, A. P. Phys. Rev. B 1998, 57, 1505-1509.

(26) Scanlon, D. O.; Walsh, A.; Morgan, B. J.; Watson, G. W. J. Phys. Chem. C 2008, 112, 9903-9911.

(27) Park, Y.-U.; Seo, D.-H.; Kwon, H.-S.; Kim, B.; Kim, J.; Kim, H.; Kim, I.; Yoo, H.-I.; Kang, K. J. Am. Chem. Soc. 2013, 135 (37), 1387013878. 